https://doi.org/10.30843/nzpp.2019.72.328

\title{
Validation of QPCR assays for the detection of citrus canker
}

Hui Wen Lee*, Wellcome W.H. Ho, Raja Thangavel, Jeyaseelan Baskarathevan and Brett J.R. Alexander

Plant Health and Environment Laboratory, Ministry for Primary Industries, PO Box 2095, Auckland 1140, New Zealand

*Corresponding author: HuiWen.Lee@mpi.govt.nz

Citrus canker, a serious bacterial disease affecting the citrus industry worldwide, is caused by Xanthomonas citri subsp. citri $(X c c)$ pathotypes $\mathrm{A}, \mathrm{A}^{*}$ and $\mathrm{A}^{\mathrm{w}}$, and to a lesser extent by X. fuscans subsp. aurantifolii $(X f a)$. The recent citrus canker outbreak in Australia has emphasised the need to re-evaluate the efficiency of molecular assays used for detecting citrus canker bacteria. Two published probe-based qPCR assays targeting the $p t h$ and $l r p$ genes were tested for $X c c$, whereas a SYBR Greenbased qPCR assay was tested for $X f a$. The Xcc pth gene and Xfa qPCR assays were shown to be specific towards all pathotypes of $X c c$ and $X f a$, respectively. The detection limit for both assays were $1 \mathrm{pg}$ of genomic DNA or $10^{3} \mathrm{CFU}$ in bacteria-spiked leaf sample. The Xcc lrp gene qPCR assay was able to discriminate $X c c$ pathotypes with a detection limit of $1 \mathrm{ng}$ of genomic DNA or $10^{6} \mathrm{CFU}$ in bacteriaspiked leaf sample, but this assay showed cross-reaction with $X f a$. To allow rapid high-throughput detection of all Xcc pathotypes, a duplex probe-based qPCR assay was developed by incorporating COX primers as an internal control for plant DNA into the $p t h$ gene qPCR assay.

https://doi.org/10.30843/nzpp.2019.72.329

\section{Heat treatments of dormant scion wood killed the European canker pathogen in planta, while chemical treatments did not}

Brent M. Fisher* and Reiny W.A. Scheper

The New Zealand Institute for Plant and Food Research Ltd, Private Bag 1401, Havelock North 4130, New Zealand

*Corresponding author: brent.fisher@plantandfood.co.nz

Neonectria ditissima, the causal agent of European canker, can be present in symptomless scion wood. Sanitation treatments could minimise this risk to nursery trees. In this trial, six heat treatments and five chemical treatments were tested for their effectiveness in removing this pathogen from dormant 'Royal Gala' wood. In July 2018, 120 symptomless inoculated shoots (three inoculations/shoot) were harvested and stored at $1^{\circ} \mathrm{C}$ for 3 months. Bundles of five inoculated shoots $(45 \mathrm{~cm})$ were placed in the centre of 24 bundles, each consisting of 25 wood pieces. Heat-treated bundles were submerged in water $\left(45^{\circ} \mathrm{C}\right.$ for $45 \mathrm{~min}$ or $50^{\circ} \mathrm{C}$ for $\left.15 \mathrm{~min}\right)$, or wrapped in moist cloth, vacuum sealed inside plastic then submerged for 3-6 h at the same temperatures. Chemical-treated bundles were submerged for $16 \mathrm{~h}$ at room temperature. Treatments were compared with untreated wood. After surface sterilising, isolation of $N$. ditissima from inoculated wounds was attempted on apple-sap amended water agar. All wounds from the untreated wood and from the chemical-treated wood yielded the pathogen. However, $N$. ditissima was not isolated from wounds that had been heat treated. Therefore, heat treatments that do not affect scion wood viability may prove an effective tool to remove European canker from nursery material. 